Property and Organization Studies

Nicolas Bencherki

TÉLUQ Montréal

nicolas.bencherki@teluq.ca

Alaric Bourgoin

HEC Montréal

alaric.bourgoin@hec.ca

A more recent version has been published in Organization Studies

https://doi.org/10.1177/0170840617745922 


\begin{abstract}
Property is pervasive, and yet we organization scholars rarely discuss it. When we do, we think of it as a black-boxed concept to explain other phenomena, rather than studying it in its own right. This may be because organization scholars tend to limit their understanding of property to its legal definition, and emphasize control and exclusion as its defining criteria. This essay wishes to crack open the black box of property and explore the many ways in which possessive relations are established. They are achieved through work, take place as we make sense of signs, are invoked into existence in our speech acts, and travel along sociomaterial networks. Through a fictionalized account of a photographic exhibition, we show that property overflows its usual legal-economic definition. Building on the case of the photographic exhibit, we show that recognizing the diversity of property changes our rapport with organization studies as a field, by unifying its approaches to the individual-vs.-collective dilemma. We conclude by noting that if theories can make a difference, then whoever controls the assignment of property - including academics who ascribe properties to their objects of study - decides not only who has or who owns what, but also who or what that person or thing can be.
\end{abstract}

Keywords: human relations and practices, performativity, property and possession, relationality 


\section{Property and Organization Studies}

Property matters. On that, both common sense and social sciences agree. Property resonates with our deepest intuitions, our most personal experiences. We cherish our own ideas, holding them close to our chests, and proudly show off our creations and accomplishments. We yearn for a space we can call our own, physical or otherwise, and we protect it with locks and passwords. We resent usurpation and sympathize with the dispossessed.

The intimacy of property may explain why the concept has permeated Western thought so profoundly. It is the very foundation of capitalism, and even Marxist critique does not reject property so much as alter the set of proprietors (c.f. Cohen, 1995, p. 173 et sq.). Property is at the root of our conceptions of personal freedom (Knowles, 1983; Radin, 1982), value (Suttie, Ginsberg, Isaacs, \& Marshall, 1935), justice (Harris, 1996) and the state (Underkuffler, 1990), and social institutions such as marriage are based on how we view property (Anderson \& Bidner, 2015). As early as Adam Smith's recognition that property 'is in reality instituted for the defence of the rich against the poor, or of those who have some property against those who have none at all' (Smith, 1776/1801, p. 167), the notion has resonated with power and resistance (see Banerjee, 2008). Perspectives on property form the infrastructure of labour relations theory (Pagano, 1991), the theory of the firm (e.g. Demsetz, 1983; Dobson, 1994) and stakeholder theory (Freeman, 1984; see also Kuhn, 2008), and underpin our understanding of organizations of all kinds. As work is increasingly 'post-bureaucratic' (Hodgson, 2004; Kellogg, Orlikowski, \& Yates, 2006), and as information technology draws us ever deeper into a service and knowledge economy built on intangibles, property has all but disappeared. It has infiltrated the interstices of our relationships, and now fuels debates over the ownership of intellectual production (e.g. Epstein, 2010) and the fragmentation and modularization of organizations and persons alike (Golden \& Geisler, 2007; Kallinikos, 2003).

Property is pervasive, and yet we organization scholars rarely discuss it. Perhaps we have accepted Talcott Parsons' 'division of labour' between economics and sociology, and assign property 
exclusively to the former (Velthuis, 1999). When we do use the notion, we take it as a black box to explain other phenomena, rather than studying it in its own right. Organization studies have adopted a restrictive view of property and its related notions, focusing on the ownership of resources through contractual arrangements. In this respect, scholars have paid great attention to investigating legal formats of firm ownership (e.g. Pinnington \& Morris, 2002) and the effects of transaction costs on firm structure and performance (Langlois, 2006). Others have considered owners' and shareholders' role in firm governance (Connelly, Hoskisson, Tihanyi, \& Certo, 2010), or what power stakeholders may wield within the organization (de Bakker \& den Hond, 2008). Such questions, however, begin with the assumption that people are shareholders or stakeholders, thus sidestepping the issue of how they may "hold" shares or stakes in the first place, and missing the opportunity to pinpoint the specifics of each form of engagement (Sloan \& Oliver, 2013; Turcotte \& Pasquero, 2001). Such views of property risk substantializing the notion by requiring the existence of a set of owners who possess, through a privileged mode, a set of things that are external to them and over which they have a right of control. In contrast, legal authors (e.g. Honoré, 1993) have recognized that there is no single form or effect of ownership, but they have done so from within a legal and/or economic stance. Indeed, as legal theorist Carol Rose (2015, p. 60) notes, “The truth is that legal definitions of possession largely refer back to legality itself. Legality [...] is the chief focal point around which social norms of property congeal."

Property, we will see, is in fact achieved in many different ways - a multiplicity that unleashes the notion's heuristic power to account for the mutual constitution of people and organizations. When we throw off our conceptual blinkers, we can look at what people who care for their organization do in their daily work and life: they have their projects, their duties, their disciplines and their departments - but also their bodies, their emotions and their friends (Ashcraft, 2008). 'Belonging to a team', 'sharing an experience', 'appropriating a skill'... the vast lexicon of property is an invitation to closely examine the practices we describe with such phrases. When we do so, we learn that what people and collectives are cannot be distinguished from what they have: beings gain existence as they acquire properties through 
additional modes; as they 'fill themselves with the world, prehend it, integrate it within' (Debaise, 2006, p. 89). It is high time, therefore, that organizational scholars cracked open the black box of property and reclaimed one of their discipline's core concepts.

Through a fictionalized account of a photographic exhibition that the first author helped organize in an underprivileged district of Montréal, Canada, we will show that property overflows its usual legaleconomic definition. The people and organizations involved in the project - a community worker, a photographer, district residents, a tenants' association, a gallery, politicians, etc. - variously established what we call possessive relations with the exhibit through work, semiotics, speech acts, materiality and legal contracts. Those relationships shaped the exhibit itself as well as its many proprietors. Building on this story, we show that recognizing the diversity of property changes our rapport with organization studies as a field, by unifying its approaches to the individual-vs.-collective dilemma. We conclude by noting that if theories can 'make a difference' (McKenzie, 2006, p.18), then whoever controls the assignment of property - including academics who ascribe properties to their objects of study - decides not only who has/owns what, but also who or what that person or thing can be. Organization studies therefore carries an important responsibility: as we define the boundaries of our field, we alter the balance of power in organizations.

\section{'We've got to take a shot of this': property through action}

The apartment block was in a state of crumbling disrepair, making one wonder how it even supported itself, let alone the families who called it home. The two visitors, their nostrils assailed by the foul stench of mould, were becoming increasingly aware of their own laboured breathing. 'Wait, wait,' said Harry to his friend Michael, 'we've got to take a shot of this hallway; I can't believe the Aman family lives in here.' Harry was a professional photographer, while Michael was a community worker with the Montréal tenants' association. Two weeks before, they had decided to bring a long-cherished project to fruition: they would organize a photographic exhibition to highlight the appalling housing conditions of the city's most underprivileged residents. Since then, they had walked the streets for hours to meet immigrant 
families, elderly people living alone, younger flatmates sharing run-down apartments and many others whose income condemned them to live on the rough side of town. When not knocking at apartment doors to negotiate photo shoots with local residents, they could be found selecting the best images of the day at Harry's studio.

Ali Aman opened the door and warmly greeted the two young men with a hot cup of tea. As they settled themselves in the humble living room, Ali affirmed that his family would be delighted to 'play a part in the project'. First, Harry photographed Ali's elderly father Hassan - who, with his earnest smile, seemed oblivious to his decrepit surroundings. The best shot, though, was of Tariq, Ali's young son, staring right at the camera as if pleading to be released from his cell. Back at Harry's studio, admiring Tariq's portrait on screen, the two men realized that their project was shaping up nicely. 'We've been toiling away like slaves,' said Harry, 'but our exhibition is going to be a blast!'

Harry and Michael describe the exhibition as 'their' project, and they are quite right: they sweated over it for weeks, agonizing over every tiny decision. Locke's 'labour theory' of property (1689/1821, sec. V), probably the most canonical in the literature, rings true here. If someone works on a project, they should share in its spoils. Even Marx's idea that private property is theft assumes the Lockean 'possessive individualism' (Macpherson, 2011): for the fruits of labour to be stolen by capitalists, they must have belonged to the workers in the first place (Cohen, 1995). Michael and Harry, though, were not working in the hope of appropriating some outcome or surplus of their work, as the theory suggests (Keyes, 1981, p. 38). The event, they hoped, would belong to the whole community. A clear separation between an activity and its outcome implies a linear and additive view, where work is but a part, along with capital, towards a product, which is the real object of value. Harry and Michael did not need an ulterior goal: they started to feel that Montréal's housing issues, the tenants' problems and, indeed, the project in itself were all theirs. Insofar as they related to them through a diversity of concrete working practices, those aspects belonged to them (Cooper, 2005; Hennion, 2015). Property is not the outcome of work, it is coextensive to it. It is accomplished by the possessive relationships one constitutes with an object through action. 
'[If] I own a can of tomato juice and spill it in the sea... do I thereby come to own the sea...?' the libertarian critic Nozick (1974, p. 74) famously asked. Of course, mixing anyone's labour with anything doesn't magically produce legal-economic property. And yet, even spilling tomato juice - say, as part of some biology research project - can create a possessive relationship between you and that portion of the sea. It's 'your' spot, where you spend hours measuring reductions in oxygen levels as the juice decays; it's 'your' dissertation fieldwork. In fact, even as he criticizes Locke, Marx and other proponents of the labour theory of property, Nozick shares with them a narrow legal-economic focus on the product of work. As soon as we understand property as a variety of possessive relations accomplished in action, the nature of these relations is no longer limited, and the black box of property can be opened.

\section{'We really belong here': semiotic relations of property}

When Harry and Michael returned to the Amans' apartment a week later, they came proudly bearing a thick portfolio of images they were considering for the exhibition, and on which they wanted the family's opinion. The group went through the photographs, discussing them and sorting them into piles. Tariq's portrait struck all those present with its forceful beauty. 'Harry and I were thinking of using this one on our promotional material,' explained Michael. 'We could use it on the exhibit's poster, as well as on our website.' Gazing at his son's image, Ali was silent for a moment before saying tearfully, 'This has a lot of meaning for us, you know.' Then he reached into his wallet, retrieved a refugee identification card, and showed it to the two visitors. 'Since we came to Montréal, we've always been strangers and on the receiving end of charity. Now you're telling us that we'll have a chance to be the ones doing the helping, thanks to this project, and that we really belong here.'

One of the most powerful ways to establish possessive relations is through the creation of meaning and the signs that make it possible. Images and photographs are semiotic devices that attach us to places, organizations and identities (Hancock, 2005; Itakura, 1994). A reputable brand strongly affiliates and controls employees through identification (Müller, 2016), and when it prints its logo on a shirt, that shirt becomes its shirt, even if the garment was stitched in a sweatshop on the other side of the 
world (Blombäck \& Axelsson, 2007). As Peirce (1958) noted, signs both depend on relations and establish them: the picture of Tariq not only reminds the Amans that they belong to Canadian society, but also effectuates that belonging, since it gives flesh to their participation in the project. The image of their son is also the image of the photographic exhibition, as it would be used on all its promotional material, and would soon be circulating around their city.

Semiotic relations of property are open to ambiguity, contradiction and polyphony. To the refugee card's representation of the Amans' paradoxical bond with their host country - indicating that they belonged in Canada, but at the same time that it was not their country - the family could now oppose another set of semiotic relations: a picture of their son that tied them to a meaningful project. The family may not legally have had a country as they still had the 'property' of being refugees, but as far as signification and significance were concerned, they were part of a neighbourhood and becoming valued contributors to their society. The multiplication of semiotic relations intensified their belonging; it allowed the Amans to have a community and, reciprocally, to belong to it (see, e.g., Derrida, 1991, p. 11 et sq.).

\section{'My administration did it': property as a speech act}

A few weeks later, the opening night of the exhibition finally arrived. Everyone was there: all the community partners, the Amans along with the other families, the press and of course a flock of politicians. Even the local borough mayor had graced the gathering with his presence. Speeches were made; glasses of effervescent enthusiasm were raised. Half the reporters were busy harassing a score of politicians about the now-obvious housing issues, while the Amans were showing off their son Tariq to the other half. At some point during the party, Michael's attention was caught by a remark the mayor made during an interview. 'The borough is happy to offer exhibitions such as this one to raise awareness of important social issues,' he said. 'It is crucial that our cultural institutions reflect the borough council's focus on housing.' 
Michael couldn't believe his ears. The mayor had held no meetings with any of them, offered nothing in the way of support and in fact had never previously shown any concern for housing issues whatsoever. Yet here he was, taking their project from under their noses in plain sight. 'It's only words,' soothed Mary, the gallery manager, when Michael told her of his outrage. He was worried that the mayor's claim would allow him to hijack the project - if not literally, then enough to taint it with his bad reputation. Michael and Harry's own stake in the project could be compromised, but most importantly the exhibit would lose its fundamental community-centred aspect - its very raison d'être.

Michael's fears were not unfounded. If property had been an intrinsic attribute and words nothing more than (mis-)representations of reality, the mayor's claim would have been harmless. But the fact is that possessive relations are also established through words. This is true even in the strictest legal sense: courts may recognize an unchallenged claim as an effective appropriation of the claimed good (Epstein, 1978; Rose, 1985). The way we speak does not merely reflect possessive relations, but also effectuates them, and constitutes certain people or things as proprietors or as property (Kockelman, 2007). At a linguistic level, possessive pronouns categorize what can be possessed and by whom (Seiler, 1983). Speech acts (see Austin, 1962) too, have the power to distribute actions and things between various beings. This is literally what the mayor is doing by attributing paternity of the exhibition to the borough. In doing so, he constitutes the borough's 'cultural institutions' and opportunistically provides them with a purpose, an agenda, even a sense of morality or virtue. At the same time, he dispossesses Michael and Harry, and therefore their community-based organization, of their work, authority and responsibilities for the project. Our properties, both in the sense of what we own and who we are, are made and unmade through words - which are never, in fact, 'just words'.

\section{'Who gets to keep the photographs?': the materiality of property}

Once the opening party had wound down, festivities continued at The Household, a nearby pub. Harry and Michael joined the group, as did Mary and Charles (the director of the Montréal tenants' association and Michael's boss). All those present celebrated the evening's success and their exhibition's promising 
future, reminiscing about their communal efforts over the past few weeks and sharing anecdotes about the party. At one point during the evening, though, Mary raised a question that put a damper on the happy mood: 'So, who gets to keep the prints once the exhibition is over?' For Mary, it was obvious that the photos should remain at her gallery. 'They're already there, so they might as well stay and become part of our permanent collection,' she suggested. 'That way our public will always have access to our pictures.'

Harry scoffed at her attempt to keep the photographs for herself, and pointed out that the longterm conservation of printed photographs was a delicate business. 'It's not the same as with paintings,' he explained. 'You've got to have the right skills and equipment.' The photographs should be stored at his studio, or they risked being lost. Michael, who was trying to accommodate everyone, ingeniously remarked, 'Couldn't we share the digital files among everyone, and whoever wants a print can just get one done?' But Charles rejected this solution, as he did not want the files to end up on the Internet where they could be copied at will by anyone.

As Mary implied, being in physical control of something is a form of possessive relation. The chair I sit on in a meeting room is 'my' chair, at least for as long as I sit on it. That's what Proudhon (1873, p. 38) called possession in fact. Again, the law may acknowledge such possessive relations: some jurisdictions recognize 'adverse possession', and grant legal title to someone tending the land of an absent owner for a given period of time (Ballantine, 1918). Possession may be the very foundation of legal property (Honoré, 1993; Rose, 1985), which is why it needs enforcement, and could regress back to brute physical force (Umbeck, 1981). War has historically served to dispossess colonized nations of their resources and lawfully appropriate them 'in the courts of the conqueror' (Banerjee, 2008). From planting a flag on a newly discovered island to destroying indigenous constructions, colonizers understood the materiality of property very well (Latour, 2010a).

Harry's argument illuminates another fact of the materiality of property: one may only own what one can own. For property to take place, one needs to tangibly care for the possessed object, but also for the network of material artefacts through which property 'passes' (Latour, 2010b). We ascertain our 
properties with documents that have physical features, from golden seals to microchips, that connect them to a complex institutional apparatus of authentication (About \& Denis, 2010). Record-keeping techniques affect an administration's level of (de-)centralization, therefore shaping the contours of (property) law and determining 'where power resides today' (Vismann, 2008, p. 164). Digital technology, by making property apparently incorporeal, has only exacerbated its controversies by subverting the spatial metaphor on which it used to rest. Property now applies to objects that are not localizable in space, and the hall of records has itself been substituted with myriads of digital traces of possessive relations - pictures on social media, files in the cloud, user names and passwords - that overflow the legal-economic perimeter of centralized government supervision (Varian, 2005).

\section{'I am the legitimate owner': the role of the contract}

The question of who would get to keep the photographs began to sour the conversation between the four friends. Finally, Charles forcefully intervened to close down the debate. 'This is a key project for the tenants' association,' he pointed out. 'We've all signed the contract that says the photographs will belong to us. I can show it to you if you've forgotten.' However, this only fanned the flames even further. 'Well, I thought the agreement only covered the way we distribute tasks among us,' protested Harry, his voice rising. 'I am not sure it's all that clear on who owns the photographs.' He reminded the group that he had agreed to work on the project at a fraction of his usual rate precisely because he could include the pictures in his portfolio and showcase his community engagement.

Charles sighed, but had to admit their agreement was ambiguous. 'Listen, I need to write in my report to the funding agency that we got something concrete out of this project, and that the association owns the photographs,' he reasoned finally. 'If you want, we can agree to license them to you, to include in your portfolio. In exchange, perhaps you could teach the gallery's staff how to handle and look after the photographs, and they could continue to exhibit them?' This proposal momentarily ended the dispute, as each one realized that even though Charles would retain legal ownership, they could all maintain the 
possessive relations that made the project worthwhile for them. Happy with this conclusion, the quartet toasted their new friendship and spent the rest of the evening envisioning future collaborations.

Contracts are the emblems of legal-economic property, and yet the enforcement of property through courts and legal contracts is exceptional and secondary to other, less formal practices (e.g. Fauchart \& von Hippel, 2008). Jurists themselves know all too well that contracts cannot account for the diversity of actual practice, and they have developed ideas much subtler than the monolithic concept of property that organization scholars borrow from them (e.g. Epstein, 1978; Honoré, 1993; Underkuffler, 1990). For instance, Rose (2015, p. 60) recognizes that owners must also rely on physical assistance to exercise their rights, for instance to 'exclude others with the help of neighbours and legal officers.' Indeed, the strength of property contracts is not transcendental; rather, it stems from their combined material and semiotic nature. As a piece of paper, a contract can be literally shown and opposed to other claims, but also bears the signs of prior agreements that lend themselves to renewed interpretation. In other words, the law and the contracts that presumably enforce it are embedded in the sociomaterial relations through which property is achieved. While invoking the contract was a way for Charles to establish himself as having the jus ad rem, as being the legal owner, the very fact that he had to invoke it shows that it neither predicts nor guarantees behaviour (c.f., Suchman, 1987). Contracts must be made to talk as people speak 'in the name of the law' (Cooren, 2015). Charles and Harry could only settle their disagreement when they laid bare the other types of possessive relations that mattered to them with respect to the photographs.

\section{Possessive relations and the mutual constitution of people and collectives}

What unites the various forms of property in Michael and Harry's case? They all contribute to shaping 'their' project and 'its' participants through the circulation of action (and its meaning) between them. This is the core of possessive relations: they establish constitutive links between beings, a link through which they reciprocally set each other in motion by sharing their actions. The initial work of the two young men gave the exhibit its first existence, while providing them, in return, with an occupation, 
and their respective legitimacy as a community worker and a photographer. The Amans offer their son's image to the exhibit, only to acquire, in the same movement, a sense of belonging to the community. When Harry, the Mayor or Mary perform speech acts in the name of the project, they also shape its contours and purpose. Reciprocally, these speakers are provided with their own contours and purpose: moral virtue for community workers, political justification for elected officials, and an artistic program for the gallery manager. The protagonists of the story negotiate the physical control of the photographs, for the materiality of the photographs provides a lasting bond to the many actions that define each one of them. The dispute over the contract showed, for its part, that while it helped decide over one legitimate owner of the photographs, it could not exhaust all the ways in which the project belonged to each protagonist.

This is why we suggest complementing the legal-economic literature's usual definition of property. The latter rests on the right or ability to control the possessed thing, which maintains a distinction between controller and controlled, and is mostly concerned with whether the relationship between both conforms with legal definitions. An alternative criterion for discriminating property is the passage of action (and its meaning) from the possessed to the possessor. Property is mutual: the possessed acts reciprocally on the possessor, in the same way as football fans win when their team wins and the team wins on behalf of its fans. Michael, Harry and the others own the exhibition not only because they have a right, in potentia or in actu, to use, discard, or capitalize on it; but also because the exhibition, in turn, provides them with a role, a purpose, a sense of belonging. It provides them, among others, with a portfolio to show for their talent and a justification for public funding. Each owner can act more and differently because the exhibit moves them, and they can partly claim its actions as their own. We care about what we own because a possessive relation constitutes us as much as we constitute what we possess, by circulating action from one to the other. This reciprocal relationship is captured, in the negative, by Nietzsche's (1896, p. 63) maxim: 'Verily, he who possesseth little is possessed still less.' 
Property, in this original sense, establishes a constitutive link between people, collectives, and things: it allows each of them to act more and differently. The possessive relations to which people participate define them. This is true for legal property, which delimits the sphere of the proper, the personal, in opposition to outside infringement (Underkuffler, 1990), but also of other forms of possession. I have a job, a task, a department, an idea, but also friends, a gender and so forth, and the things I have participate to what I am. They also make me do things I could not do without them - the joys and hardships of my friends are also mine, the talent of my colleagues makes me proud, the prestige of my job shines on me. To have great luck is to be lucky; to have subordinates is to be their superior; to have students is to be a teacher. As Greimas explains, 'to have' and 'to be' express 'the same logical function' (1987, p. 88), and there is something artificial in opposing property's both senses - what defines me vs what I own - which share the same etymological root.

Property, however, is also, in the same movement, the creative principle of collectives, as it necessarily implies alterity, in at least two ways. First, property both supposes and causes the possessed thing to be different from me. From the moment I speak of 'my' arm, I am stressing that it is not 'me.' Similarly, Latour (2005, p. 204) speaks of the 'plug-ins' that supplement human beings: the methods, instruments, apps and other gizmos we own and that help us calculate, be smarter and more perceptive, but that can be taken away, break down or betray us. Property therefore always involves improperty, a reality Derrida (1994, p. 112) called exappropriation: a thing that would entirely be mine would not be my property, since it would not be distinct from me. I can change, become someone different, because I may gain properties or let them go. In this first sense, property reveals that the individual is already collective, made up of many parts thanks to an effort (as small as it may seem to an able-bodied, soundminded person). Second, property takes on new meanings as it is shared with others. I can be similar to my peers, belong to a community, identify with my company, because we share properties: values, traditions, aspirations, goals. I am part of a family because my spouse and I have a history, a house, and kids in common. While sharing may appear as a form of dispossession, it also makes property 
meaningful. 'Sentimental value', for instance, stems from the object having belonged to someone else - a parent, a friend, a lover (Belk, 1988); a consulting assignment's value proceeds from the consultant's ability to have the client appropriate his work and deliverables (Bourgoin, 2015). It is because the exhibition came to belong to the Amans and other families, and because Harry and Michael shared it together, that it was so precious to each one of them, but also that they became a team. Common property creates a common identity, as well as a need to coordinate the way the sharing takes place: the everyday life of organizations is driven by controversies over responsibility for tasks and duties; attribution of credit; ownership of roles, projects, ideas and so forth. Even when I must dispossess someone of something in order to own it, it is precisely the shared nature of property - or at least of the bid for property - that determines the value of the good: it is the number would-be proprietors for a same good that makes it rare, and therefore valuable from an economic standpoint. The reason for controversies over property is that we know very well that what we have determines what we can do and who we can be, individually and collectively.

When it is not reduced to its legal-economic understanding, and when it is looked at from outside of the discipline of the law, property appears as layered and potentially polyphonic phenomena. Indeed, a thing, idea or person may have 'as many senses as there are forces capable of taking possession of it' (Deleuze, 1983, p. 4). 'My' office means something different to me than it means to the State auditor who compiles the government's real estate assets. Of course, possessive relations of different kinds, including the legal one, can align with each other, creating a densification of property, which then appears simple and non-problematic. Sometimes, though, they don't, especially in organizations, which are crossroad of people, technologies and ideas with competing interests, and indeed possessive relations. In those cases, property ceases to be a stable explanans of the social, and rather reveals itself as an explanandum that requires explication in itself. Shifting from the first posture to the second makes us realize the role property plays in organizations, and how reclaiming the concept may shift our understanding of organizational action and constitution. 


\section{Property and organization studies}

In organization studies, considerable effort has gone into attempting to reconnect individual and organizational action (see Weik, 2011) through various theoretical lenses. They all stress different facets of the organization, which are exactly the ones that guide our vignettes: action, semiotics, speech acts, materiality and legality. An emphasis on property helps us understand that, despite the apparent diversity of approaches in our field, we researchers do, in fact, have a core agreement. We all struggle, in our own way, with the sharing, appropriating, attributing, etc., that is implicated as organizations are constituted, and with a different type of possessive relations through which that goal is accomplished. In other words, organization scholars have been in agreement across our diverse theoretical approaches, but perhaps we must return to a first principle - property - to understand why. When we do so, new questions can be asked, and answered, across perspectives. In the remainder of this essay, we take a first look at what these new questions and answers may look like.

First and foremost, a property lens specifies perspectives based on action, such as practice-based research (e.g. Orlikowski, 2010), performativity (Gond, Cabantous, Harding, \& Learmonth, 2016) and processuality (Chia \& Tsoukas, 2003; Langley, 1999). Here, a key question posed by the concept of property is: 'Whose actions are we talking about?' This brings us back to the very origin of organizations: the first companies were created to carry out activities that only made sense when accomplished jointly (such as religious groups; North, 1979), or to share resources and risks when embarking on maritime explorations (see Wills, 1993). Enabling more action - as when the tenants' association, the photographer, the families, and the gallery join forces - is the key role property plays in the constitution of organizations: an organization's various 'owners' own a share of its greater capacity to act. This was understood by pioneering organization scholars, including Mary Parker Follett (Follett, 1940; see Snider, 1998) and Chester Barnard (1938/1968), for whom 'contribution' - as the giving or sharing of action with the collective - was a key theoretical and empirical concern. How action moves from the individual to the organization, and the other way around, is considered in the works of a handful of scholars, including 
Cooren's (2010) 'ventriloquism' theory, Czarniawska's (2004) 'action nets', and Taylor and Van Every's reliance on French narratologist A. J. Greimas' 'actantial' model (Taylor \& Van Every, 2011). Researchers from ethnomethodology or workplace ethnography (e.g. Hutchins, 1995; Llewellyn \& Hindmarsh, 2010) also focus on how action is shared among interactants. Looking at these works through the lens of property reveals that organizations exist as the (partial) possessors of people, things and action: the organization acts inasmuch as it has employees, has machines, has buildings, has intellectual property and so forth, so that their actions are also its own. However, this relation is mutual: I can act more attract students and funding, go to conferences, work on exciting projects - precisely because I am (partially) possessed by my university. Understanding the link between individual and organizational action, therefore, amounts to tracing the movements through which an organization may appropriate a variety of actions, and vice versa.

From a meaning-based perspective, this sharing of action may be considered as what psychologists have called 'attribution' (see Harvey, Madison, Martinko, Crook, \& Crook, 2014). The term makes it clear that this process establishes a possessive relation; however, attribution theory locates those relations in the meaning-making processes of people. In this sense, it aligns with interpretive perspectives on organizing (Putnam \& Pacanowsky, 1983), which look at how people interpret environmental clues to choose a course of action (see e.g. Mills, 2002; Weick, 1993). This view of attribution, however, has two limitations when interrogated from a property viewpoint. First, it fails to account for the fact that Tariq's picture or the refugee card were quite tangible, and rested on real efforts to be produced or obtained, on computer networks to circulate or authenticate them, and so forth. The Amans did not just 'think' they belonged; they could prove it. In that sense, attribution is not only cognitive, but also as social and material as the signs and symbols that perform it. Second, when considered as happening in people's minds, it is not clear whose attributions count towards the constitution of the organization, and whose are dismissed. Concretely, this means that interpretive researchers should not assume, for instance, that interviews with only formal members provides a 
complete picture of the organization, since membership itself is the outcome of polyphonic and ambiguous attributions (Bencherki \& Snack, 2016). Again, this entails decentering the study of signs, symbols and meaning from an exclusive focus on individual people, to allow a more comprehensive observation of the ways in which they contribute to establishing possessive relations.

In that sense, signs and symbols do not merely refer to realities and entities that already exist; they also create new ones (Austin, 1962). As in the case of our borough mayor above, Robichaud (2003) explains how, at a town hall meeting, a mayor tells stories that link various narratives describing activities and, thus, appropriates those threads to weave the city's action. Language, through speech acts, brings about organizational reality (Cooren, 2000), whether in face-to-face interaction (e.g. Bencherki, Matte, \& Pelletier, 2016; Bencherki \& Cooren, 2011), in writing (Brummans, 2007; Cooren, 2004) or through technology (Taylor \& Virgili, 2008). Speech acts construct (social) reality: couples are married when the priest says 'I now pronounce you...', and institutional facts such as money, baseball or human rights exist in and through language use (Searle, 1995). This ability, we contend, rests in part on language's participation in the establishing of possessive relations. For instance, speech acts attribute the interaction between two individuals to a broader recognizable institution (this conversation is a 'meeting', that one was a 'pep talk', etc.) by establishing that ' $\mathrm{X}$ counts as $\mathrm{Y}$ in context C' (Searle, 1995, p. 28; see also Taylor \& Van Every, 2011). Accounting practices, in the same vein, not only reflect an organization, but also write down the possessive relation through which the organization 'has' people, buildings, equipment and actions (Quattrone, 2004). A property lens clarifies that what speech acts do is attribute the actions that constitute organizations and make them act. Rules, protocols and standards, in that sense, are so many speech acts that operate attributions; when those attributions repeat themselves steadily, we iteratively produce collectives, organizations, nations and other apparently abstract entities.

Possessive relations endure and can repeat thanks to the durability of materiality, among other reasons. The town hall meeting minutes will continue describing actions as the city's long after the mayor retires. The accounting books of the Jesuits continue to tell us about their organizational structure. The 
pictures will outlast the exhibit, showing that the Amans belong to their community. Software, slide decks and other documents turn a consultant's individual field experience into their firm's collective knowledge, even after they move on (Bourgoin, Bencherki, \& Cooren, 2017; Schoeneborn, 2013). Materiality, it follows, detaches attribution from an author's initial intention, making it autonomous (Derrida, 1988). Artifacts and technology in organizations become what Deleuze and Guattari (1987, p. 424) call 'apparatuses of capture': people, work and actions are routinely appropriated by the organization thanks to the inscription of rules and protocols into machines and objects. Time and attendance software appropriates the work done during clock-in hours (Paulsen, 2013). Personal files I store on a shared drive may be reaped by my employer (Franklin, 2012). The autonomy of attribution poses important ethical dilemmas, especially by making action impersonal. The materiality of property draws attention to the mechanisms that naturalize dispossession and disempowerment, but also invites us to think critically about how we deflect responsibility. For instance, a graduated stick used by Doctors Without Borders to identify children tall enough to receive medical care transfers the heartbreaking choice from each individual to the organization, so that it becomes its decision (Cooren \& Matte, 2010). Materiality depersonalizes action, but in doing so, also incorporates it into the organizational body.

Given the polymorphous nature of property, conflicts between attempts to establish possessive relations are inevitable. To handle such cases, a stable legal system that predictably resolves disputes is essential to business (Lau \& Johnson, 2012; Perry, 2000). The law, then, may appear to be an overarching framework in which organizations operate. Many subfields in organization studies, including studies on transparency, corporate social responsibility or alternative organizations, have had difficulty moving past the legal origins of these notions (for exceptions, see Flyverbom \& Albu, 2017; Jensen \& Sandstrom, 2011; Paranque \& Willmott, 2014). An important example of how the definition of property may expand beyond its legal scope is the shift in focus from shareholders to stakeholders (West, 2016). By recognizing that the organization does not only pertain to its owners in a narrow sense, this shift has unshackled governance and made 'participation' a hot topic (see Putterman, 1988), especially when it 
comes to CSR (Morsing \& Schultz, 2006). A broader understanding of property also subsumes the duality between organization and market that situates production either inside the firm (by owning productive equipment) or outside it (by buying goods from providers) (Ouchi, 1980; Williamson, 1985). Coworking and creative spaces, fablabs incubators, telework, volunteering and other new forms of work and production where space, equipment or even labour are shared can only be understood from an organization lens when property is cracked open (Gandini, 2015; Leca, Gond, \& Barin Cruz, 2014; McNamee \& Peterson, 2014). It follows that the law and its courts must deal with several forms of possessive relations at once. As an example, when users sued Apple after discovering that iPhones collected location data, the court adjudicated between two modes of property: the phone, as a literal 'apparatus of capture', appropriated users' movements, while the text of the end-user agreement stated that those movements belonged to users alone (Bishop, 2013). The number of modes of property that a decision - whether from a judge or a manager - considers is finally what may differentiate between it being merely legal or conclusively ethical. For instance, appropriating an employee's private emails on their work computer may be lawful, but still not quite the 'right' thing to do, for such an appropriation fails to account for other modes of property that link the emails to the employee (Brandeisky, 2015). Organizations are 'legal entities' but it is time that we, organizational scholars, recognized that the law accounts for a richer reality than we have granted it.

\section{Conclusion}

More than yet another object of study for our existing theories, property calls for a different way of theorizing. Property is an empirical matter; whether an organization has these or those members, buildings, brands, partners, missions, markets, and so forth, is an observable achievement, rather than an assured starting point for inquiry (see e.g. Bencherki \& Snack, 2016). Property concerns both what someone or something has and what he / she / it is, and we must resist defining people, organizations, or other things before we study the possessive relations that constitute them. Our studies, as researchers, are so many bundles of speech acts through which we attribute properties to organizations and other beings. 
As our research gain traction outside academia, then we normalize the fact that organizations 'have' their environment, their stakeholders, their human capital, their intangible assets, their intellectual property, and so forth. We turn various things into possessions available for the organization to manage, capitalize on, or otherwise deal with.

In doing so, researchers are also appropriating objects to constitute the field of organization studies. If we show that stakeholders belong to 'their' organization, then they also become our problem. As we attributed all sorts of possessions to organizations, we have also expanded our own capacity to act; from a narrow focus on work processes in manufactures, we now discuss urban planning, the arts, climate change, and a score of issues to the extent that, we claim, pertain to organization studies. This extension of organization studies is possible because organizations are 'bits and pieces from the social, the technical, the conceptual, and the textual [...] fitted together' (Law, 1992, p. 381) through possessive relations. Property establishes connections between beings of different ontologies, channels actions from one of the other, and constitutes the organization not only as property - as a contractual perspective would consider - but also as the meeting point of its properties.

In a sense, our suggestion may be read as agreeing with capitalism and its critiques: property is at the heart of organizations and our work relations. Capitalism, however, operates by suggesting that one particular mode of property is superior to others, one that channels surplus value upward and lets some of it 'trickle down.' A renewed critique may consist not in fighting against property, but in multiplying the forms it takes, to allow everyone - managers, workers, stakeholders, customers - to have a share in their collective endeavor and to retain a portion of their machines, ideas, responsibilities, space, colleagues, even without a piece of paper that bears witness to their contribution. In fact, post-industrial production has shifted property from things to information, making such a broader definition of property inevitable (Casey, 1996; Hill, 1974). Relatedly, authors have described property's role in power relations (Cohen, 1995; Galbraith, 1983). That role can be more precisely pinpointed when property is understood as the circulation of action: indeed, the appropriation of means of production, the purchase of labor, and the 
privatization of space and natural resources (Baer, 2014; Low, 2006), are so many ways to augment one's repertoire of actions, but also to limit the activities and identities available to others.

By capturing more practices and people in the net of property, a more generous and ecumenical definition of property has the potential to open the door to other proprietors, and shift the balance of power. Property, as a constitutive element of both people and collectives, is the seed for a theory of the world we own in common and that we must care for together. It draws attention to our responsibility for our possessions, for ourselves and for each other, as society is, after all, in the words of Gabriel Tarde (1893, p. 42), 'the reciprocal possession, under extremely varied forms, of all by each'. 


\section{References}

About, I., \& Denis, V. (2010). Histoire de l'identification des personnes. Paris: La Découverte.

Anderson, S., \& Bidner, C. (2015). Property Rights over Marital Transfers. The Quarterly Journal of Economics, 130, 1421-1484.

Ashcraft, K. L. (2008). Bringing the body back to work, whatever and wherever that is: Occupational evolution, segregation, and identity. In Annual Meeting of the National Communication Association.

Austin, J. L. (1962). How to Do Things with Words. Cambridge, MA: Harvard Univ. Press.

Baer, M. (2014). Private Water, Public Good: Water Privatization and State Capacity in Chile. Studies in Comparative International Development, 49, 141-167.

Ballantine, H. W. (1918). Title by Adverse Possession. Harvard Law Review, 32, 135-159.

Banerjee, S. B. (2008). Necrocapitalism. Organization Studies, 29, 1541-1563.

Barnard, C. (1968). The functions of the executive. Cambridge: Harvard University Press. (Original work published 1938)

Belk, R. W. (1988). Possessions and the Extended Self. Journal of Consumer Research, 15, 139-168.

Bencherki, N., \& Cooren, F. (2011). Having to be: the possessive constitution of organization. Human Relations, 64, 1579-1607.

Bencherki, N., Matte, F., \& Pelletier, É. (2016). Rebuilding Babel: A Constitutive Approach to Tonguesin-use. Journal of Communication, 66, 766-788.

Bencherki, N., \& Snack, J. P. (2016). Contributorship and Partial Inclusion: A Communicative Perspective. Management Communication Quarterly, 30, 279-304.

Bishop, B. (2013, November 27). iPhone location-tracking lawsuit against Apple is dismissed. The Verge.

Blombäck, A., \& Axelsson, B. (2007). The role of corporate brand image in the selection of new subcontractors. Journal of Business \& Industrial Marketing, 22, 418-430.

Bourgoin, A. (2015). Les équilibristes, une ethnographie du conseil en management. Paris: Presses des Mines.

Bourgoin, A., Bencherki, N., \& Cooren, F. (2017). Questioning the paradox of knowledge commodification. Presented at the European Group for Organizational Studies, Copenhagen, Denmark.

Brandeisky, K. (2015, March 5). 5 Things You Didn't Know About Using Personal Email at Work. Retrieved September 1, 2017, from http://time.com/money/3729939/work-personal-email-hillaryclinton-byod/

Brummans, B. H. J. M. (2007). Death by document: Tracing the agency of a text. Qualitative Inquiry, 13, 711-727.

Casey, C. (1996). Corporate Transformations: Designer Culture, Designer Employees and 'PostOccupational' Solidarity. Organization, 3, 317-339.

Chia, R., \& Tsoukas, H. (2003). Everything Flows and Nothing Abides: Towards A "Rhizomic" Model of Organizational Change, Transformation and Action. Process Studies, 32, 196-224.

Cohen, G. (1995). Self-Ownership, Freedom, and Equality. Cambridge, UK: Cambride University Press. 
Connelly, B. L., Hoskisson, R. E., Tihanyi, L., \& Certo, S. T. (2010). Ownership as a Form of Corporate Governance. Journal of Management Studies, 47, 1561-1589.

Cooper, R. (2005). Peripheral Vision Relationality. Organization Studies, 26, 1689-1710.

Cooren, F. (2000). The organizing property of communication. Amsterdam/Philadelphia: J. Benjamins.

Cooren, F. (2004). Textual agency: How texts do things in organizational settings. Organization, 11, 373393.

Cooren, F. (2010). Action and Agency in Dialogue: Passion, Ventriloquism and Incarnation. Amsterdam/Philadelphia: John Benjamins.

Cooren, F. (2015). In the name of law: Ventriloquism and juridical matters. In K. McGee (Ed.), Latour and the passage of law (pp. 235-272). Edinburgh, UK: Edinburgh University Press.

Cooren, F., \& Matte, F. (2010). For a constitutive pragmatics: Obama, Médecins Sans Frontières and the measuring stick. Pragmatics and Society, 1, 9-31.

Czarniawska, B. (2004). On Time, Space, and Action Nets. Organization, 11, 773-791.

de Bakker, F. G. A., \& den Hond, F. (2008). Introducing the Politics of Stakeholder Influence: A Review Essay. Business \& Society, 47, 8-20.

Debaise, D. (2006). Un empirisme spéculatif: lecture de Procès et réalité de Whitehead. Paris: Vrin.

Deleuze, G. (1983). Nietzsche and Philosophy. London: Athlon Press.

Deleuze, G., \& Guattari, F. (1987). A thousand plateaus : capitalism and schizophrenia. Minneapolis: University of Minnesota Press.

Demsetz, H. (1983). The structure of ownership and the theory of the firm. Journal of Law and Economics, 26, 375-389.

Derrida, J. (1988). Signature, Event, Context. In Limited Inc. (pp. 1-23). Evanston, IL: Northwestern University Press.

Derrida, J. (1991). L'autre cap ; suivi de La démocratie ajournée. Paris: Editions de Minuit.

Derrida, J. (1994). Specters of Marx: the state of the debt, the work of mourning, and the New international. New York: Routledge.

Dobson, J. (1994). Theory of the Firm. Economics and Philosophy, 10, 73.

Epstein, R. A. (1978). Possession as the Root of Title. Georgia Law Review, 13, 1221.

Epstein, R. A. (2010). The disintegration of intellectual property? A classical liberal response to a premature obituary. Stanford Law Review, 455-521.

Fauchart, E., \& von Hippel, E. (2008). Norms-Based Intellectual Property Systems: The Case of French Chefs. Organization Science, 19, 187-201.

Flyverbom, M., \& Albu, O. B. (2017). Transparency. In The International Encyclopedia of Organizational Communication. John Wiley \& Sons, Inc. doi:10.1002/9781118955567.wbieoc210

Follett, M. P. (1940). The Psychology of Consent and Participation. In The Dynamic Administration: The Collected Papers of Mary Parker Follett (pp. 196-217). London: Routledge.

Franklin, S. (2012). Cloud Control, or The Network as Medium. Cultural Politics an International Journal, 8, 443-464.

Freeman, R. E. (1984). Strategic management: a stakeholder approach. Boston: Pitman. 
Galbraith, J. K. (1983). The Anatomy of Power. Boston, MA: Houghton Mifflin.

Gandini, A. (2015). The rise of coworking spaces: A literature review. Ephemera, 15, 193.

Golden, A. G., \& Geisler, C. (2007). Work-life boundary management and the personal digital assistant. Human Relations, 60, 519-551.

Gond, J.-P., Cabantous, L., Harding, N., \& Learmonth, M. (2016). What Do We Mean by Performativity in Organizational and Management Theory? The Uses and Abuses of Performativity. International Journal of Management Reviews, 18, 440-463.

Greimas, A. J. (1987). On meaning: selected writings in semiotic theory. Minneapolis: University of Minnesota Press.

Hancock, P. (2005). Uncovering the Semiotic in Organizational Aesthetics. Organization, 12, $29-50$.

Harris, J. W. (1996). Property and justice. Oxford: Clarendon Press.

Harvey, P., Madison, K., Martinko, M., Crook, T. R., \& Crook, T. A. (2014). Attribution Theory in the Organizational Sciences: The Road Traveled and the Path Ahead. Academy of Management Perspectives, 28, 128-146.

Hennion, A. (2015). Enquêter sur nos attachements. Comment hériter de William James? SociologieS. Retrieved from http://sociologies.revues.org.proxy.bibliotheques.uqam.ca:2048/4953

Hill, R. (1974). The Coming Of Post Industrial Society. Critical Sociology, 4, 37.

Hodgson, D. E. (2004). Project Work: The Legacy of Bureaucratic Control in the Post-Bureaucratic Organization. Organization, 11, 81-100.

Honoré, A. M. (1993). Ownership. In P. Smith (Ed.), The Nature and Process of Law: An Introduction to Legal Philosophy (pp. 370-375). New York, NY: Oxford University Press.

Hutchins, E. (1995). How a Cockpit Remembers Its Speeds. Cognitive Science, 19, 265-288.

Itakura, S. (1994). Symbolic representation of possession in a chimpanzee. In S. T. Parker, R. W. Mitchell, \& M. L. Boccia (Eds.), Self-awareness in animals and humans: Developmental perspectives (pp. 241-247). New York, NY, US: Cambridge University Press.

Jensen, T., \& Sandstrom, J. (2011). Stakeholder Theory and Globalization: The Challenges of Power and Responsibility. Organization Studies, 32, 473-488.

Kallinikos, J. (2003). Work, Human Agency and Organizational Forms: An Anatomy of Fragmentation. Organization Studies, 24, 595-618.

Kellogg, K. C., Orlikowski, W. J., \& Yates, J. (2006). Life in the trading zone: Structuring coordination across boundaries in postbureaucratic organizations. Organization Science, 17, 22-44.

Keyes, T. W. (1981). Karl Marx on Property (Ph.D.). Marquette University, Milwaukee, WI. Retrieved from http://search.proquest.com/docview/303183896/abstract

Knowles, D. (1983). Hegel on Property and Personality. The Philosophical Quarterly, 33, 45.

Kockelman, P. (2007). Inalienable possession and personhood in a Q'eqchi'-Mayan community. Language in Society, 36, 343-369.

Kuhn, T. (2008). A Communicative Theory of the Firm: Developing an Alternative Perspective on Intraorganizational Power and Stakeholder Relationships. Organization Studies, 29, 1227-1254.

Langley, A. (1999). Strategies for theorizing from process data. Academy of Management Review, 24 , 691-710. 
Langlois, R. N. (2006). The Secret Life of Mundane Transaction Costs. Organization Studies, 27, 13891410.

Latour, B. (2005). Reassembling the social: an introduction to actor-network-theory. Oxford ; New York: Oxford University Press.

Latour, B. (2010a). On the modern cult of the factish gods. Durham, NC: Duke University Press.

Latour, B. (2010b). The making of law: An ethnography of the Conseil d'Etat. (M. Brilman \& A. Pottage, Trans.). Cambridge, UK: Polity.

Lau, T., \& Johnson, L. (2012). Importance of Rule of Law to Business. In Business and the Legal and Ethical Environment. Boston, MA: FlatWorld.

Law, J. (1992). Notes on the theory of the actor-network: Ordering, strategy, and heterogeneity. Systems Practice, 5, 379-393.

Leca, B., Gond, J.-P., \& Barin Cruz, L. (2014). Building 'Critical Performativity Engines’ for deprived communities: The construction of popular cooperative incubators in Brazil. Organization, 21, $683-712$.

Llewellyn, N., \& Hindmarsh, J. (2010). Organisation, interaction and practice : studies in ethnomethodology and conversation analysis. Cambridge, UK; New York: Cambridge University Press.

Locke, J. (1821). Two treatises of government. London: Whitmore and Fenn, and C. Brown. (Original work published 1689)

Low, S. M. (2006). The Erosion of Public Space and the Public Realm: paranoia, surveillance and privatization in New York City. City \& Society, 18, 43-49.

Macpherson, C. B. (2011). The political theory of possessive individualism: Hobbes to Locke. Don Mills, ON: Oxford University Press.

McNamee, L. G., \& Peterson, B. L. (2014). Reconciling “Third Space/Place” Toward a Complementary Dialectical Understanding of Volunteer Management. Management Communication Quarterly, 28, 214-243.

Mills, C. (2002). The Hidden Dimension of Blue-collar Sensemaking about Workplace Communication. Journal of Business Communication, 39, 288-313.

Morsing, M., \& Schultz, M. (2006). Corporate social responsibility communication: stakeholder information, response and involvement strategies. Business Ethics: A European Review, 15, 323 338.

Müller, M. (2016). 'Brand-Centred Control': A Study of Internal Branding and Normative Control. Organization Studies, 0170840616663238.

Nietzsche, F. W. (1896). Thus Spake Zarathustra: A Book for All and None. (A. Tille, Trans.). New York: Macmillan.

North, J. A. (1979). Religious toleration in Republican Rome. Proceedings of the Cambridge Philological Society, 25, 85-103.

Nozick, R. (1974). Anarchy, state, and utopia. New York: Basic Books. Retrieved from http://www.loc.gov/catdir/enhancements/fy0832/73091081-b.html

Orlikowski, W. J. (2010). Engaging Practice in Research: Phenomenon, Perspective, and Philosophy. In D. Golsorkhi, L. Rouleau, D. Seidl, \& E. Vaara (Eds.), The Cambridge Handbook on Strategy as Practice (pp. 23-33). Cambridge, UK: Cambridge University Press. 
Ouchi, W. G. (1980). Markets, Bureaucracies and Clans. Administrative Science Quarterly, 25, 129-141.

Pagano, U. (1991). Property rights, asset specificity, and the division of labour under alternative capitalist relations. Cambridge Journal of Economics, 15, 315-342.

Paranque, B., \& Willmott, H. (2014). Cooperatives—saviours or gravediggers of capitalism? Critical performativity and the John Lewis Partnership. Organization, 21, 604-625.

Paulsen, R. (2013). Non-work at work: resistance or what? Organization. doi:10.1177/1350508413515541

Peirce, C. S. (1958). The Collected Papers of Charles Sanders Peirce. (A. W. Burks, Ed.) (Vol. VIIVIII). Cambridge, MA: Harvard University Press.

Perry, A. (2000). An Ideal Legal System for Attracting Foreign Direct Investment? Some Theory and Reality. American University International Law Review, 15, 1627-1657.

Pinnington, A., \& Morris, T. (2002). Transforming the architect: Ownership form and archetype change. Organization Studies, 23, 189-210.

Proudhon, P.-J. (1873). Qu'est-ce que la propriété? (2nd ed.). Paris: A. Lacroix et Cie.

Putnam, L. L., \& Pacanowsky, M. E. (1983). Communication and organizations, an interpretive approach. Beverly Hills: Sage Publications. Retrieved from http://www.loc.gov/catdir/enhancements/fy0660/83013702-d.html

Putterman, L. (1988). The Firm as Association Versus the Firm as Commodity. Economics and Philosophy, 4, 243.

Quattrone, P. (2004). Accounting for God: accounting and accountability practices in the Society of Jesus (Italy, XVI-XVII centuries). Accounting, Organizations and Society, 29, 647-683.

Radin, M. J. (1982). Property and Personhood. Stanford Law Review, 34, 957.

Robichaud, D. (2003). Narrative institutions we organize by: The case of a municipal administration. In B. Czarniawska \& P. Gagliardi (Eds.), Narratives we organize by: Advances in organization studies (pp. 37-54). Amsterdam: John Benjamins.

Rose, C. M. (1985). Possession as the Origin of Property. The University of Chicago Law Review, 52, 7373.

Rose, C. M. (2015). The law is nine-tenths of possession: an adage turned on its head. In Y.-C. Chang (Ed.), Law and Economics of Possession (pp. 40-64). Cambridge: Cambridge University Press.

Schoeneborn, D. (2013). The pervasive power of PowerPoint: How a genre of professional communication permeates organizational communication. Organization Studies, 34, 1777-1801.

Searle, J. R. (1995). The construction of social reality. New York; Toronto: Free Press.

Seiler, H. (1983). Possession as an operational dimension of language. Tübingen: G. Narr.

Sloan, P., \& Oliver, D. (2013). Building trust in multi-stakeholder partnerships: Critical emotional incidents and practices of engagement. Organization Studies, 0170840613495018.

Smith, A. (1801). An inquiry into the nature and causes of the wealth of nations (6th ed., Vol. 2). Dublin: N. Kelly. (Original work published 1776)

Snider, K. (1998). Living Pragmatism: The Case of Mary Parker Follett. Administrative Theory \& Praxis, 20, 274-286.

Suchman, L. (1987). Plans and situated action: the problem of human-machine interaction. Cambridge: Cambridge University Press. 
Suttie, I. D., Ginsberg, M., Isaacs, S., \& Marshall, T. H. (1935). A symposium on property and possessiveness. British Journal of Medical Psychology, 15, 51-83.

Tarde, G. (1893). Monadologie et sociologie. (J.-M. Tremblay, Ed.). Chicoutimi, QC: J.-M. Tremblay.

Taylor, J. R., \& Van Every, E. J. (2011). The situated organization: Studies in the pragmatics of communication research. New York, NY: Routledge.

Taylor, J. R., \& Virgili, S. (2008). Why ERPs Disappoint: the Importance of Getting the Organisational Text Right. In B. Grabot, A. Mayère, \& I. Bazet (Eds.), ERP Systems and Organisational Change (pp. 59-84). Springer, London.

Turcotte, M.-F., \& Pasquero, J. (2001). The Paradox of Multistakeholder Collaborative Roundtables. The Journal of Applied Behavioral Science, 37, 447-464.

Umbeck, J. (1981). Might makes rights: A theory of the formation and initial distribution of property rights. Economic Inquiry, 19, 38-59.

Underkuffler, L. S. (1990). On Property: An Essay. The Yale Law Journal, 100, 127.

Varian, H. R. (2005). Copying and copyright. The Journal of Economic Perspectives, 19, 121-138.

Velthuis, O. (1999). The Changing Relationship between Economic Sociology and Institutional Economics: From Talcott Parsons to Mark Granovetter. American Journal of Economics and Sociology, 58, 629-649.

Vismann, C. (2008). Files: law and media technology. (G. Winthrop-Young, Trans.). Stanford, CA: Stanford University Press.

Weick, K. E. (1993). The collapse of sensemaking in organizations: The Mann Gulch disaster. Administrative Science Quarterly, 628-652.

Weik, E. (2011). In Deep Waters: process theory between Scylla and Charybdis. Organization, 18, 655672.

West, A. (2016). Applying Metaethical and Normative Claims of Moral Relativism to (Shareholder and Stakeholder) Models of Corporate Governance. Journal of Business Ethics, 135, 199-215.

Williamson, O. E. (1985). The economic institutions of capitalism: firms, markets, relational contracting. New York, NY: Free Press.

Wills, J. E. (1993). Maritime Asia, 1500-1800: The Interactive Emergence of European Domination. The American Historical Review, 98, 83. 